1st International Conference - Global Ethics - Key of Sustainability (GEKoS) | May 15th, 2020 | Bucharest, Romania

\title{
The Relationship between Tax Evasion and Corruption. A Cross-country Examination.
}

\author{
Cristina TIMOFTE (COCA), Dorel MATES, Dan-Andrei COCA, \\ Simona-Maria TANASA (BRINZARU)
}

https://doi.org/10.18662/lumproc/gekos2020/18

How to cite: Timofte (Coca), C., Mates, D., Coca, D.-A., \& Tanasa (Brinzaru), S.-M. (2020). The Relationship between Tax Evasion and Corruption. A Cross-country Examination. In A. Grigorescu \& V. Radu (vol. ed.), Lumen Proceedings: Vol. 11. 1st International Conference Global Ethics Key of Sustainability (GEKoS) (pp. 173-181). Iasi, Romania: LUMEN Publishing House. https://doi.org/10.18662/lumproc/gekos2020/18 


\title{
The Relationship between Tax Evasion and Corruption. A Cross-country Examination.
}

\author{
Cristina TIMOFTE (COCA) ${ }^{1 *}$, Dorel MATES², Dan-Andrei COCA 3 , \\ Simona-Maria TANASA (BRINZARU) ${ }^{4}$
}

Abstract

This article investigates the relationship between tax evasion and corruption, in order to determine if there can be found a significant connection between the two, and in order to test previous research results that found tax evasion as being positively related to corruption. Moreover, the research examines if tax evasion could be predicted based on data regarding corruption. To this extent, theoretical bypothesis on how corruption influences tax evasion were developed and empirically tested. The research was carried on a cross-country data for the 28 European Union's Member States for the period 2012 - 2017 and it used IBM SPSS Statistics 20 in order to analyze and interpret the results. The main finding is that corruption is statistically significantly related to tax evasion and that such relationship is a positive one, as highly corrupt countries also register high levels of tax evasion - as measured by the proxy values used. These findings could be of great use for policymakers all around the world, as a policy against corruption could have major implications on tax evasion and vice versa.

Keywords: Corruption; European Union; Tax Evasion; VAT gap.

\footnotetext{
${ }^{1}$ Ştefan cel Mare University, Suceava, Romania, e-mail: cristinat.coca@gmail.com

2 West University, Timisoara, Romania, e-mail: mates.doloro60@yahoo.com

${ }^{3}$ Ştefan cel Mare University, Suceava, Romania, e-mail: coca.danandrei@gmail.com

${ }^{4}$ Ştefan cel Mare University, Suceava, Romania, e-mail: tanasa simona19@yahoo.com

(c) The Authors, LUMEN Conference Center \& LUMEN Proceedings.

Selection and peer-review under responsibility of the Organizing Committee of the conference
} 


\section{Introduction}

Traditionally, the threats, risks and vulnerabilities to the wellbeing and security of the state are evaluated through military concepts, but the current environment requires an extended approach, covering elements of social, political and economical nature.

Corruption and tax evasion [1] are two distructive activities, which often work hand in hand, sapping the state`s authority.

According to legal literature [14] tax evasion is ,the logic result of the inadvertencies and oversights of an imperfect legislation, of the inefficient means of enforcement and of the lacunose regulations". The state`s lack of foresight when enacting laws is as culpable as those who commit fraud.

One definition for tax evasion is breaking the law knowingly so that one may obtain monetary benefits to the detriment of the general state budget, usually through tax noncompliance [19].

No matter the definition, tax evasion represents, in fact, not fulfilling ones fiscal obligations to the state. Manifesting itself in a limitless domain, tax evasion is as varied as the taxes that are implemented.

It is generally undisputed that theoretically tax evasion has two main forms of display: the legal form (tax avoidance) and the fraudulent/illicit one [5], [6], [11].

Settling the boundaries of this grey area is raising difficulties, but defining lawful and illicit is useful because it enables properly estimating and ascertaining the causes of this phenomenon.

According to The World Bank, corruption reflects ,the illegal use of public resources with the aim of personal gain" [17]. On the same note, Transparency International defines corruption ,as the abuse of power in order to obtain private benefits" [20].

In our opinion, corruption can be defined as an illegal and immoral use of power, connections and/or of collective or public resources in order to obtain for oneself or someone close undue advantages and/or monetary benefits.

\section{Problem Statement}

Some previous studies conducted regarding the relationship between $\operatorname{tax}$ evasion and corruption found that the latter increases the size of the shadow economy - which is caused mainly by tax evasion. 
According to [22], corruption usually occurs alongside other major financial crimes such as tax evasion, embezzelment, money laundering or tax fraud.

Also, according to some authors [7] corruption and the shadow economy - proxy measure for tax evasion - are complements only in the countries that register low incomes.

Previous research [9] has also found that shadow economy and corruption are substitutesand that variability in the latter increases shadow economy.

Other studies (10) [10] show that tax evasion does not influence corruption activities, while the budgetary repercussions of tax evasion induce less corruption.

Moreover, other findings [13] suggests that at an international level, tax compliance is related to bureaucracy (inverse relationship) and to the successful control of corruption (positive relationship). Also, there is suggestive evidence [2] that corruption (bribes) increase where there can be found opportunities for tax evasion activities.Also, more corruption enables the existence of more tax evasion, as some studies concluded [3].

Furthermore, some findings [12] suggest that the perception of corruption is related to the motivation ofcompanies to engage in the earnings'manipulation, especiallyfor those located in emerging countries.

This paper's contribution to the current literature is the issuance of new proofs on the relationship between tax evasion and corruption. By taking a comprehensive theoretical and empirical approach, by using more up-to-date data and information, this research extends on prior studies which tested similar relationships.

\section{Research Questions/Aims of the research}

In the context described above, this study aims to answer the following research question: Does corruption, as measured by the corruption perception index influences tax evasion at country level? In order to answer it, the following hypotheses will be tested:

- Hypothesis 1. There is aneither positive or a negative statistically significant relationship between corruption and tax evasion.

- Hypothesis 2. Tax evasion could be predicted based on data regarding corruption. 
Cristina TIMOFTE (COCA) et al. | Lumen Proceedings 11 | GEKoS2020

\section{Research Methods}

The research methodology can be structured as follows:

- Determining the proxy measure for the level of tax evasion in the European Union's Member States (including United Kingdom): the VAT Gap (European Commission).

As shown in a great number of works [4] , [15], [18] tax evasion is a phenomenon whose measurment is especially difficult to be made, due to its nature, as it cannot be directly observed. In this context, in this study, a proxy measure is used instead of tax evasion (the VAT gap), as the indirect taxes are considered to be the most significant component of the shadow economy, together with unemployment [16].

- Determining the proxy measure for the level of corruption in the European Union's Member States (including United Kingdom): the Corruption Perceptions Index(Transparency International).

In order to test the hypotheses the perceptions-based indices of corruption from Transparency Intenational were used as mean values for the period 2012 - 2017 for the analysed European Union Member States.

- Establishing the timespan of the research according to data availability: 2012 - 2017;

- Retreiving the necessary data from the following sources:The VAT Gap in the European Union's Member States during 2012 - 2017 from the European Commission [8]; The Corruption Perceptions Index in EU Member States during 2012 - 2017 from Transparency International [21];

- Computing the mean for the VAT Gap and for the CPI for the chosen time period, variables used in order to minimize measurment errors;

Table 1: The VAT Gap mean and CPI mean in European Union's Member States during 2012 - 2017.Source:own processing

\begin{tabular}{|c|l|c|c|}
\hline No. & \multicolumn{1}{|c|}{ Country } & VAT gap mean 2012 - 2017 & CPI mean 2012 - 2017 \\
\hline 1 & Austria & 8,62 & 72,67 \\
\hline 2 & Belgium & 11,38 & 75,83 \\
\hline 3 & Bulgaria & 17,95 & 41,67 \\
\hline 4 & Croatia & 3,78 & 48,50 \\
\hline 5 & Cyprus & 5,34 & 60,83 \\
\hline 6 & Czech Republic & 16,60 & 52,67 \\
\hline 7 & Denmark & 10,05 & 90,33 \\
\hline 8 & Estonia & 9,20 & 68,67 \\
\hline
\end{tabular}


Cristina TIMOFTE (COCA) et al. | Lumen Proceedings 11 | GEKoS2020

\begin{tabular}{|c|l|c|c|}
\hline & Finland & 6,41 & 88,67 \\
\hline 10 & France & 11,45 & 70,00 \\
\hline 11 & Germany & 10,75 & 79,83 \\
\hline 12 & Greece & 30,32 & 42,83 \\
\hline 13 & Hungary & 17,38 & 51,17 \\
\hline 14 & Ireland & 11,86 & 72,83 \\
\hline 15 & Italy & 27,20 & 44,83 \\
\hline 16 & Latvia & 18,53 & 54,50 \\
\hline 17 & Lithuania & 26,38 & 58,00 \\
\hline 18 & Luxembourg & 2,14 & 81,00 \\
\hline 19 & Malta & 15,44 & 55,83 \\
\hline 20 & Netherlands & 7,96 & 83,67 \\
\hline 21 & Poland & 22,87 & 60,50 \\
\hline 22 & Portugal & 13,07 & 62,67 \\
\hline 23 & Romania & 37,39 & 45,33 \\
\hline 24 & Slovakia & 29,44 & 49,17 \\
\hline 25 & Slovenia & 7,40 & 59,67 \\
\hline 26 & Spain & 6,52 & 59,50 \\
\hline 27 & Sweden & 3,13 & 87,50 \\
\hline 28 & United Kingdom & 11,17 & 78,67 \\
\hline
\end{tabular}

- Performing the linear regression analysis in IBM SPSS Statistics 20, setting as dependent variable the mean VAT gap for the period 2012 2017 - as a proxy measure for tax evasion and as independent variable the data regarding the mean of the corruption perceptions index for each of the EU Member States for the same time period;

- Interpreting and illustrating the results;

- Answering the research hypotheses.

\section{Findings}

In order to verify the type of relationship between tax evasion and corruption, as well as to verify whether tax evasion could be predicted based on data regarding corruption, the linear regression in IBM SPSS Statistics 20 was performed, setting as dependent variable the mean VAT gap as a percentage of VAT Total Tax Liability for the analysed countries for the period 2012 - 2017 - as a proxy measure for tax evasion and as independent variable the data regarding the mean of the corruption perceptions index for 
Cristina TIMOFTE (COCA) et al. | Lumen Proceedings 11 | GEKoS2020

each of the EU Member States for the same time period. The following results were obtained:

Table2: Results of the linear regression analysis in IBM SPSS Statistics, Source: own computation

\begin{tabular}{|c|c|c|c|c|c|c|c|c|c|}
\hline \multicolumn{1}{|c|}{$\begin{array}{c}\text { Mod } \\
\text { el }\end{array}$} & R value & $\begin{array}{c}\text { R2 } \\
\text { value }\end{array}$ & $\begin{array}{c}\text { Adjusted } \\
\text { R2 }\end{array}$ & Std. Error & R2 Ch. & F Ch. & df1 & df2 & $\begin{array}{c}\text { Sig. F } \\
\text { Ch. }\end{array}$ \\
\hline 1 &, $661^{\text {a }}$ &, 437 &, 415 & 6,9794156 &, 437 & 20,171 & 1 & 26 &, 000 \\
\hline
\end{tabular}

According to Table 2, there is a high degree of correlation between the two sets of data as the $\mathrm{R}$-value is 0,661. Furthermore, the R2 value indicates that $43,70 \%$ of the total variation in the dependent variable (tax evasion), can be explained by the independent variable (corruption perceptions).

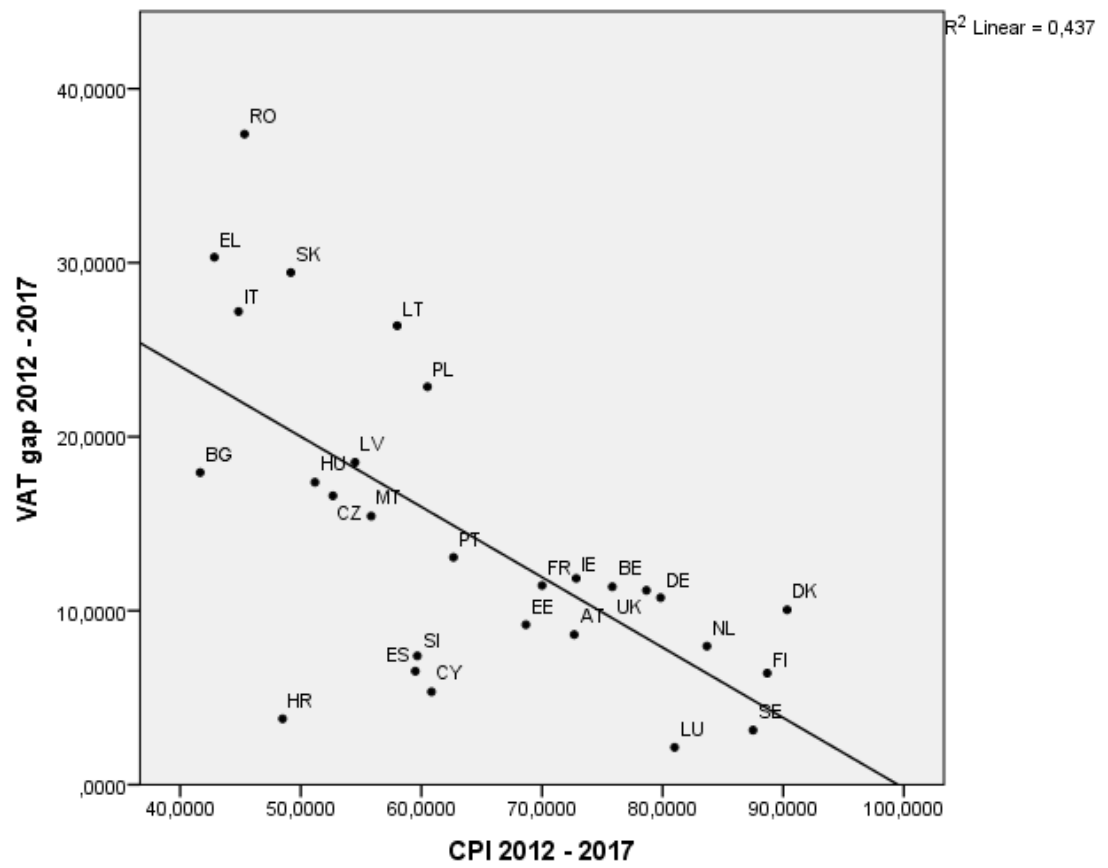

Figure 1.Results of the linear regression analysis in IBM SPSS Statistics. Source: own computation 
As shown in Figure 1, on one hand, Luxemburg $(2,14)$ and Sweden $(3,13)$ are the countries with the lowest levels of tax evasion, as measured by the VAT gap mean for 2012 - 2017. As per the corruption perception index mean for 2012 - 2017 Luxemburg registers 81 points and Sweden 87,50, thus situating themselves among the countries with the lowest levels of corruption also.

On the other hand, the highest levels of tax evasion are registered in Romania $(37,39)$ and Greece $(30,32)$, countries that also register low values for the corruption perceptions indexes mean for 2012 - 2017 (Romania 45,33; Greece - 42,83), thus placing themselves among the most corrupt countries from the dataset along with Bulgaria $(41,67)$.

The lowest levels of corruption as measured by the corruption perception index mean for 2012 - 2017 are registered in Denmark $(90,33)$ and Finland $(88,67)$, countries with quite low levels of tax evasion also (Denmark - 10,05; Finland - 6,41), as measured by the VAT gap mean.

\section{Conclusions}

In what concerns the tested research hypotheses, it can be concluded that Hypothesis 1. There is an either positive or a negative statistically significant relationship between corruption and tax evasion, was validated as tax evasion was found as being positively related to corruption as highly corrupt countries (Greece, Romania) also register high levels of tax evasion - as measured by the proxy values, while clean countries (Finland, Sweden, Luxembourg) register quite low levels of tax evasion.

However, inverse relationship between the analysed phenomena were found as an exception in countries such as Croatia and Spain. In this context, Croatia registered a very low VAT gap mean for 2012 - 2017 (thus a low level of tax evasion) of 3,78, ranking itself in the third position from the 28 countries and a very low level of the corruption perception index mean for 2012 - 2017 (thus a high level of corruption) of 48,50, ranking itself on the 24th position among the 28 analysed countries. Similarly, Spain registered quite low levels of tax evasion (rank 6-6,52) and quite high levels of corruption (rank $17-59,50$ ).

Hypothesis 2. Tax evasion could be predicted based on data regarding corruption was also validated through the research, as it was found that there is a significant correlation between the two datasets and that $43,70 \%$ of the total variation in the dependent variable (tax evasion), can be explained by the independent variable (corruption perceptions index). 
Thus, corruption - as measured by the Corruption Perceptions Index from Transparency Intenational was found to be statistically positively related to and a significant determinant of tax evasion, as measured by the proxy - VAT gap extracted from the European Commission's Eurostat database.

These findings could be of great use for policymakers all around the world, as a policy against corruption could have major implications on tax evasion and vice versa.

\section{Acknowledgement}

This work is supported by project POCU 125040, entitled "Development of the tertiary university education to support the economic growth PROGRESSIO", co-financed by the European Social Fund under the Human Capital Operational Program 2014-2020.

\section{References}

[1] Achim MV. Corupția şi economia subterană. Teorii şi studii. Cluj-Napoca: Presa Universitară Clujană; 2017.

[2] Alm J, Liu Y, Zhang K. Financial constraints and firm tax evasion. Int Tax Public Finance. 2019 Feb 1; 26(1):71-102.

[3] Alm J, Martinez-Vazquez J, McClellan C. Corruption and firm tax evasion. Journal of Economic Behavior \& Organization. 2016 Apr; 124:146-63.

[4] Alm J. Measuring, explaining, and controlling tax evasion: lessons from theory, experiments, and field studies. Int Tax Public Finance. 2012 Feb 1;19(1):54-77.

[5] Anitei NC, Lazar RE. Evaziunea fiscala intre legalitate si infractiune. Iaşi: Editura Lumen; 2013.

[6] Dinga E. Considerații teoretice privind evaziunea fiscală vs. frauda fiscală (Theoretical considerations on tax evasion vs. tax fraud). Studii Financiare Abordări teoretice şi modelare, București [Internet]. 2008;(4/2008). Available from: ftp://ftp.repec.org/opt/ReDIF/RePEc/vls/vls _pdf/ vol12i4p2050.pdf

[7] Dreher A, Schneider F. Corruption and the shadow economy: an empirical analysis. Public Choice. 2010 Jul;144(1-2):215-38.

[8] European Commission [Internet]. Studies and Reports on the VAT Gap in the EU-28 Member States. Available from: https://ec.europa.eu/

[9] Goel RK, Saunoris JW. Does variability in crimes affect other crimes? The case of international corruption and shadow economy. Applied Economics. 2019 Jan 14;51(3): 239-58.

[10] Goerke L. Bureaucratic corruption and profit tax evasion. Economics of Governance. 2008 May;9(2):177-96. 
[11] Grosu V. The Dimension of Tax Evasion in Romania. Ecoforum Journal. 2018; 7(2):4.

[12] Lourenço IC, Rathke A, Santana V, Branco MC. The Effects of Corruption on Earnings Management. 2017; 26.

[13] Picur RD, Riahi-Belkaoui A. The impact of bureaucracy, corruption and tax compliance. Review of Accounting and Finance; 2006. Available from: https://www.emerald.com/insight/content/doi/10.1108/147577006106689 85/ full/html

[14] Şaguna D. Drept financiar şi fiscal. Bucureşti: Ed. All Beck; 2003.

[15] Schneider F, Buehn A. Estimating the Size of the Shadow Economy: Methods, Problems and Open Questions. IZA Discussion Paper. 2016; (9820): 42.

[16] Schneider F, Raczkowski K, Mróz B. Shadow economy and tax evasion in the EU. J of Money Laundering Control. 2015 Jan 5;18(1):34-51.

[17] The World Bank [Internet]. World Bank. Available from: https://www.worldbank.org/en/topic/governance/brief/anti-corruption

[18] Timofte C, Socoliuc M, Grosu V. Measuring Tax Evasion. Conceptual Approaches. The USV Annals of Economics and Public Administration. 2019; Vol 19 1(29).

[19] Timofte C, Socoliuc M. Tax Evasion - From Its Roots to Its Branches. Ecoforum Journal. 2019;8 (1). 6 p.

[20] Transparency International [Internet]. [cited 2019 Sep 23]. Available from: https://www.transparency.org/glossary

[21] Transparency International. Corruption Perceptions Index 2017 [Internet]. Available from: https://www.transparency.org/news/feature/corruption_perceptions_index _2017.

[22] World Bank, OECD. Improving Co-operation between Tax Authorities and Anti-Corruption Authorities in Combating Tax Crime and Corruption [Internet]. World Bank; 2018. Available from: http://elibrary.worldbank.org/doi/book/10.1596/30911 